\title{
Comparative Efficacy of Bacillus thuringiensis Commercial Formulations against Leaf Worm, Spodoptera litura Fabricius under Laboratory Conditions
}

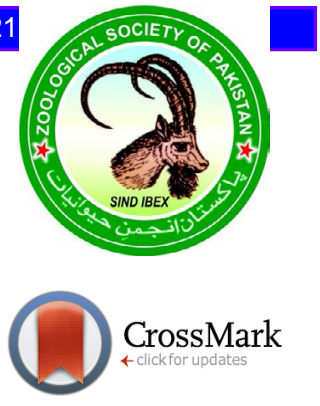

\author{
Ammara Blouch ${ }^{1}$, Ata ul Mohsin ${ }^{2}$, Muhammad Naeem ${ }^{2}$ and Rashid Mahmood ${ }^{1 *}$ \\ ${ }^{1}$ Honeybee Research Institute, National Agricultural Research Centre, Islamabad \\ ${ }^{2}$ Department of Entomology, Pir Mehr Ali Shah Arid Agriculture University, Rawalpindi
}

\begin{abstract}
A B S T RA C T
A study was carried out in the Bio-control Laboratory, Department of Entomology at Pir Mehr Ali Shah, Arid Agriculture University Rawalpindi to check the efficacy of commercial biopesticides under controlled environmental conditions. Bio pesticides are important alternates for chemical control of economically damaging insect pests like leaf worm, Spodoptera litura Fabricius. In this study, two commercial products including Dipel with Bt sub speciess kurstaki and Turex with Bt sub speciess kurstaki and aizawai were tested against three early larval instars of $S$. litura under laboratory conditions using leaf dip method. Mortality was recorded after three and seven days of exposure. The results indicated that larval mortality increased with time and Turex (Bt sub speciess kurstaki and aizawai) after 3 days of exposure caused significantly higher mortality i.e $46.43,43.45$ and $38.69 \%$ as compared to Dipel (Bt sub speciess kurstaki) that caused $19.05,6.55$ and $4.76 \%$ mortality for $1^{\text {st }}, 2^{\text {nd }}$ and $3^{\text {rd }}$ instar, respectively. The data for $7^{\text {th }}$ day also showed significantly higher mortality as $64.29,60.71$ and $45.24 \%$ by Turex (Bt sub speciess kurstaki and aizawai) in comparison with $55.95,57.74$ and $42.86 \%$ mortality by Dipel (Bt sub species kurstaki) for $1^{\text {st }} 2^{\text {nd }}$ and $3^{\text {rd }}$ instar, respectively. Susceptibility to both bio pesticides increased with increase in their concentration and decreased with increase in larval instar. Similarly $\mathrm{LC}_{50}$ values suggested Turex (Bt sub species kurstaki and aizawai) to be more toxic with less $\mathrm{LC}_{50}$ values as compared to Dipel (Bt sub species kurstaki). These results indicated that these bio pesticides if used at early insect stage can help to control this pest.
\end{abstract}

\begin{tabular}{l} 
Article Information \\
Received 19 June 2018 \\
Revised 01 May 2019 \\
Accepted 10 June 2019 \\
Available online 24 January 2020 \\
Authors' Contribution \\
\hline AB designed and carried out the study \\
and wrote the manuscript. AM and \\
MN supervised the research work. RM \\
drafted the manuscript. \\
Key words \\
\hline $\begin{array}{l}\text { Spodoptera litura, Bacillus } \\
\text { thuringiensis, Commercial } \\
\text { formulations, Laboratory bioassays }\end{array}$
\end{tabular}

\section{INTRODUCTION}

L eaf worm, Spodoptera litura (Fab.) is one of the most voracious and damaging insect pest of more than one hundred host plants with important cultivated crops and vegetables in the South Asian countries (Qin et al., 2004). It is also known as leaf worm, common or tobacco cutworm and cluster or tobacco caterpillar. Under favourable environmental conditions, its population grows rapidly and it moves across the field like an army therefore it is called as "Armyworm". It causes major economic losses to crops and in severe situation, a total crop loss (Dhir et al., 1992; Singh and Sachan, 1992). Heavy losses in field crops have been estimated (25-50\%) depending upon the population density of this pest (Patil et al., 1991). Warm and humid field conditions of South Asia favor its development, multiplication and resurgence (Ahmad et al., 2007). It has the ability to multiply at very

\footnotetext{
* Corresponding author: rashid ento1@yahoo.com 0030-9923/2020/0002-0609 \$ 9.00/0

Copyright 2020 Zoological Society of Pakistan
}

fast rate, polyphagous in nature and can travel to long distances making it a very difficult pest to manage in outbreak situations (Ahmad et al., 2007). The infestation of S. litura in Pakistan usually starts at the end of March and continues till the end of November depending upon the cropping pattern (Sayyed et al., 2008). This pest is abundantly found during the months of September and October (Islam et al., 1984). Its outbreak occurs due to insecticide resistance, favorable weather conditions and heavy rainfall after a long dry period (Thanki et al., 2003).

Spodoptera litura is well known for its quick development of resistance to different groups of insecticides used to manage it (Kranthi et al., 2002). Different control methods including biological, physical and chemical are practiced for its management (Parera et al., 2000). However, chemical control method is the most common but its extensive use has resulted in serious resistance problems. Extensive use of synthetic insecticides is not only detrimental for the environmental but also results in high chemical and labour costs (Ding et al., 1998). Alternate host plants of S. litura like arum (Arum maculatum), Elephant ear (Colocasia esculenta) 
and Desert Horsepurslane, (Triamthema portulacasterum) can help to reduce the development of pest on major crops (Ahmad, 2008).

Variable levels of resistance to almost every group of insecticides have been observed in Pakistan, India and China in S. litura field populations. The resistance has been found to develop in both conventional insecticide groups like organochlorine, organophosphate, carbamates and pyrethroids as well as in new chemistry insecticides like indoxacarb, abamectin, and emamectin (Kranthi et al., 2002; Ahmad et al., 2008). The pesticides use not only results in such resistance problems but also causes health hazards to operators like farmers and the surrounding environment (Tinoco- Ojanguren and Halperin, 1998).

Currently, the use of microbes for controlling economically important pests has increased. Bacillus thuringiensis products have been tried on a very large scale because of their effectiveness against insects and safety to environment and humans (Falcon, 1971). It is a rod-shaped gram positive soil bacterium that produces crystal proteins which are toxic to certain insects but are harmless to the humans, wildlife and beneficial insects and considered to be the most important environmentally safe bio pesticides against agricultural pests (Butter et al., 1995; Puri et al., 1998). Keeping in view the importance of $B$. thuringiensis, two commercial formulations were tested against three first larval stages of $S$. litura under laboratory conditions because $S$. litura is a gregarious feeder and need to be controlled at three first larval stages to avoid extensive crop damage and economic losses and also due to the fact that $B t$ toxins are most effective for three first larval stages.

\section{MATERIALS AND METHODS}

\section{Field collection and rearing of Spodoptera litura}

The study was carried out in the Bio-control Laboratory, Department of Entomology at Pir Mehr Ali Shah, Arid Agriculture University Rawalpindi under controlled environmental conditions. About 200 larvae of $S$. litura were collected from the cauliflower growing areas of Bahawalpur, where a number of insecticides are used for management of different insect pests. According to a study for the determination of Pesticide residues in Bahawalpur soil, the most widely detected pesticides which are being used heavily in Bahawalpur included mevinphos, endosulfan, fenitrothion, chlorpyriphos dichlorvos, dimethoate and methyl parathion (Anwar et al., 2014). Spodoptera litura larvae were kept in a plastic jar of about 2 litre volumes with some host plant leaves (Cauliflower). The jar was closed with a piece of muslin cloth and brought to laboratory for further rearing at
$25 \pm 2^{\circ} \mathrm{C}, 50 \pm 10 \%$ relative humidity and $16 \mathrm{hr}$ photoperiod. The collected larvae were reared in six hole Petri dishes on artificial wheat germ based diet (Ahmad et al., 2007). After 3-4 days larval diet was replaced with new one and the cells were cleaned for further rearing of larvae till pupation. Mature pupae were collected with the help of a forceps and were kept in separate plastic box lined with tissue paper. Emerged adult moths were shifted to plastic jars of $4 \mathrm{~kg}$ capacity covered with muslin cloth and were provided $10 \%$ sugar solution. Egg batches were collected daily from the tissue paper strips hanged inside the jars.

\section{Test bioinsecticides and bioassays}

Commercial formulations of two Bacillus thuringiensis strains including Dipel with $B t$ sub species kurstaki and Turex with Bt sub species kurstaki and aizawai were used for laboratory bioassays. Dipel potency was 16,000 i.u/mg. While the potency of Turex (WP) was 32,000 i.u/mg. Dipel was product of Valent Bio-Science U.S.A. and Turex was a product of Abbot Laboratories. Bioassays were conducted using leaf dip method against early three instars of $S$. litura (Anonymous, 1990). A stock solution based on preliminary bioassays of $B t$ insecticides was prepared in distilled water and diluted by $1 / 2$ to 6 serial levels of concentration as $200,100,50,25,12.5$ and $6.25 \mathrm{mg} /$ $\mathrm{ml}$. Leaf discs of $5 \mathrm{~cm}$ diameter were cut using $5 \mathrm{~cm}$ diameter leaf cutter from the unsprayed host plant (cauliflower) and were washed with tap water and air-dried before use. These leaf discs were dipped in each test solution level for 10-15 seconds with gentle agitation and air-dried in fume hood. The treated leaf discs with their adaxial side upward were then placed in petri dishes of $5 \mathrm{~cm}$ diameter that contained moist filter paper at their bottom to avoid desiccation. Four leaf discs (replications) per concentration level with 20 larvae at each level were used (Total larvae $=120$ ). Five $1^{\text {st }}, 2^{\text {nd }}$ and $3^{\text {rd }}$ instar larvae of S. litura were released in each Petri dish using camel hair brush. In case of control, the leaves were dipped in distilled water.

\section{Statistical analysis}

Larval mortality was recorded after three and seven days of exposure period. Larvae that could not respond to stimulation with a blunt head needle or bodies deformed were considered as dead. Abbot's formula was used to calculate the corrected mortality (Abbot, 1925) and was analyzed by probit analysis (Finney, 1971). The results were interpreted using POLO-PC software (Russell et al., 1977) and means were compared using Duncan Multiple range test $(\mathrm{P}<0.05)$. 


\section{RESULTS AND DISCUSSION}

The data of mean mortalities after $3^{\text {rd }}$ and $7^{\text {th }}$ day of exposure showed $1^{\text {st }}$ instar and $2^{\text {nd }}$ instar larvae to be more susceptible to both the formulations; Dipel (Bt sub species kurstaki) and Turex (Bt sub species kurstaki and aizawai) as compared to $3^{\text {rd }}$ instar. For $1^{\text {st }}$ instar, Dipel caused 19.05 and $55.95 \%$ mortality, while Turex caused 46.43 and $64.29 \%$ mortality after $3^{\text {rd }}$ and $7^{\text {th }}$ day of application, respectively. For $2^{\text {nd }}$ instar, Dipel caused 6.55 and 57.74 $\%$ mortality and Turex caused 43.45 and $60.7 \%$ mortality after $3^{\text {rd }}$ and $7^{\text {th }}$ day, respectively. Similarly, for $3^{\text {rd }}$ instar Dipel caused 4.76 and $42.86 \%$ mortality while Turex caused 38.69 and $45.24 \%$ mortality after $3^{\text {rd }}$ and $7^{\text {th }}$ day of exposure, respectively (Table I). Thus, mortality was higher for $1^{\text {st }}$ and $2^{\text {nd }}$ instar larvae as compared to $3^{\text {rd }}$ instar larvae in case of both formulations. These results are in accordance with those of Puntambekar et al. (1997) who tested different $\mathrm{Bt}$ strains against certain lepidopteran pests and determined that use of 1018 spores per ml of Bt var. kurstaki (NCIM 2514) caused $85 \%$ mortality in neonate larvae of S. litura and Pthorimae operculella. Sondos et al. (2000) also reported that Bt toxins were most effective for the newly hatched larvae of $S$. littoralis.

This Comparison of mean mortalities of the S. litura larvae through Duncan's Multiple Range test also indicated that the Turex formulation caused more mortality as compared to Dipel after both $3^{\text {rd }}$ and $7^{\text {th }}$ day of application. This further revealed that for all the three instars, there exists a significant difference between the mortality caused by both Insecticides on $3^{\text {rd }}$ day. However, $7^{\text {th }}$ day data of $1^{\text {st }}$ and $2^{\text {nd }}$ instars showed non-significant difference among the efficacy of two $B t$ formulations. DMR test also revealed that performance of each commercial formulation was statistically different at different levels of concentration. There is highly significant difference in mean mortality between highest and lowest concentration level of both insecticides i.e. $200 \mathrm{mg}$ and $6.25 \mathrm{mg}$ (Table I).

The toxicity data (Table II) also showed that $1^{\text {st }}$ and $2^{\text {nd }}$ instars were less significantly different regarding their susceptibility on $7^{\text {th }}$ day as compared to $3^{\text {rd }}$ instar which showed highly significant difference on both $3^{\text {rd }}$ and $7^{\text {th }}$ day for both commercial formulations. These results are in accordance with Loganathan et al. (2002) who also found that for the management of S. litura spraying with bio pesticides in the early stages is most effective.

The Toxicity values of both formulations (Table II) also suggested that Turex containing mixture of two strains was more toxic and was found to be more effective to control this pest with less $\mathrm{LC}_{50}$ values of $12.6,15.9$ and 26.0 on $3^{\text {rd }}$ day and $3.50,3.85$ and 14.1 on $7^{\text {th }}$ day as compared to Dipel with $\mathrm{LC}_{50}$ values of 144, 295 and 426 on $3^{\text {rd }}$ day and $5.59,3.45$ and 19.81 on $7^{\text {th }}$ day for $1^{\text {st }} 2^{\text {nd }}$ and $3^{\text {rd }}$ instar respectively.

Graphical representation of data has also shown that with increasing level of concentration, mortality of larvae also increased. However, on $7^{\text {th }}$ day mortality was high for all the instars irrespective of the dose level used showing that time factor plays a key role in the mortality in case of slow-acting insecticides like Bt (Figs. 1, 2 and 3).
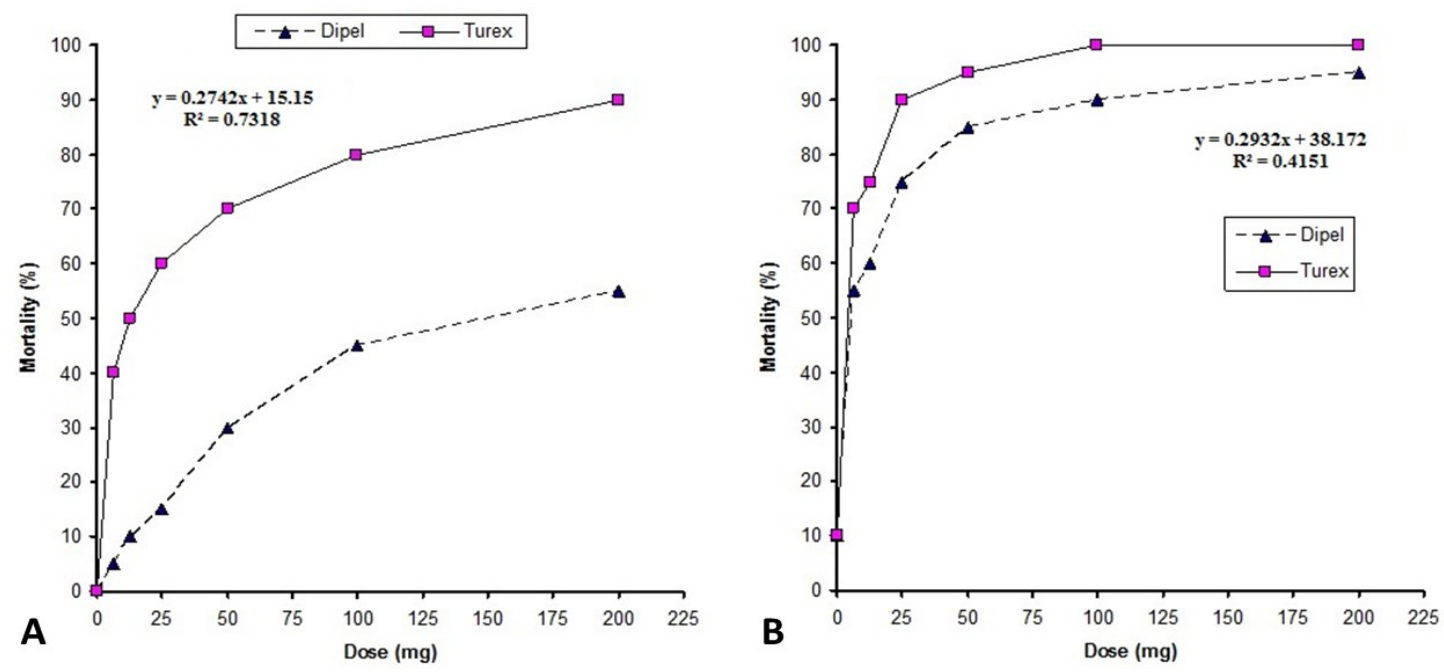

Fig. 1. Mortaity of $1^{\text {st }}$ instar larvae Spodoptera litura against Dipel and Turex on $3^{\text {rd }}$ day (A) and on $7^{\text {th }}$ day (B) of application of insecticide. 

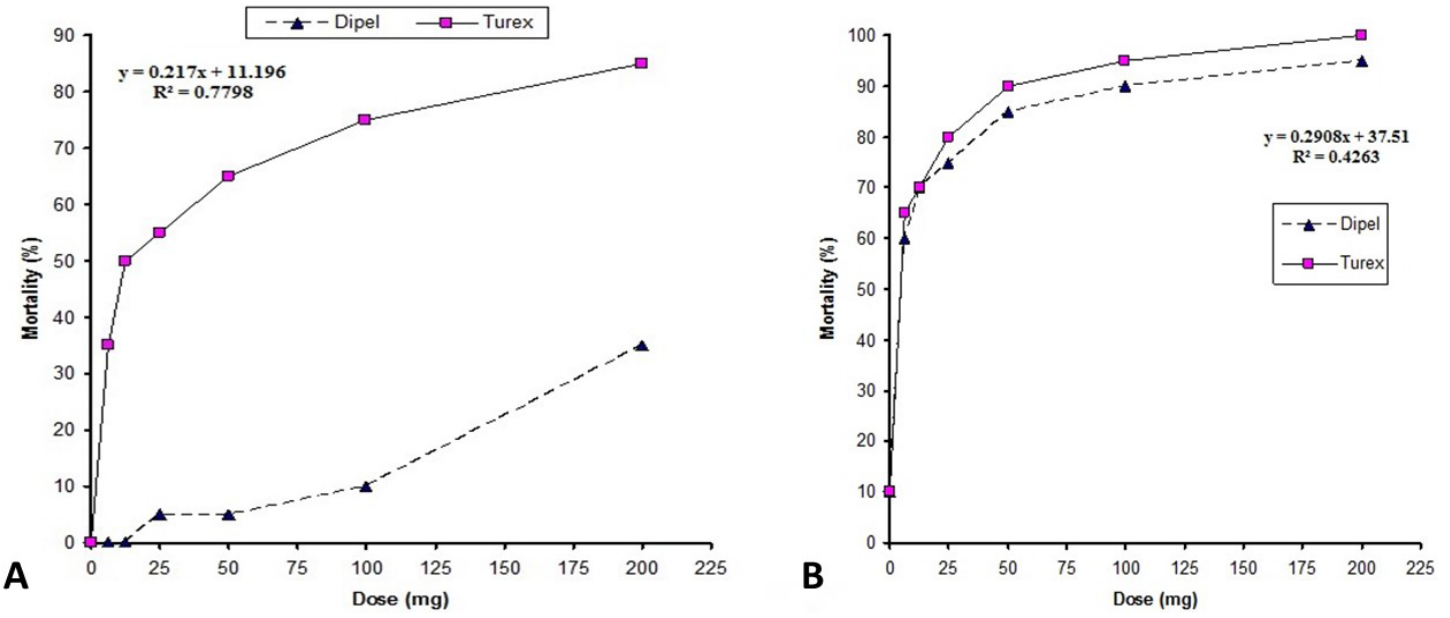

Fig. 2. Mortaity of $2^{\text {nd }}$ instar larvae Spodoptera litura against Dipel and Turex on $3^{\text {rd }}$ day (A) and on $7^{\text {th }}$ day (B) of application of insecticide.
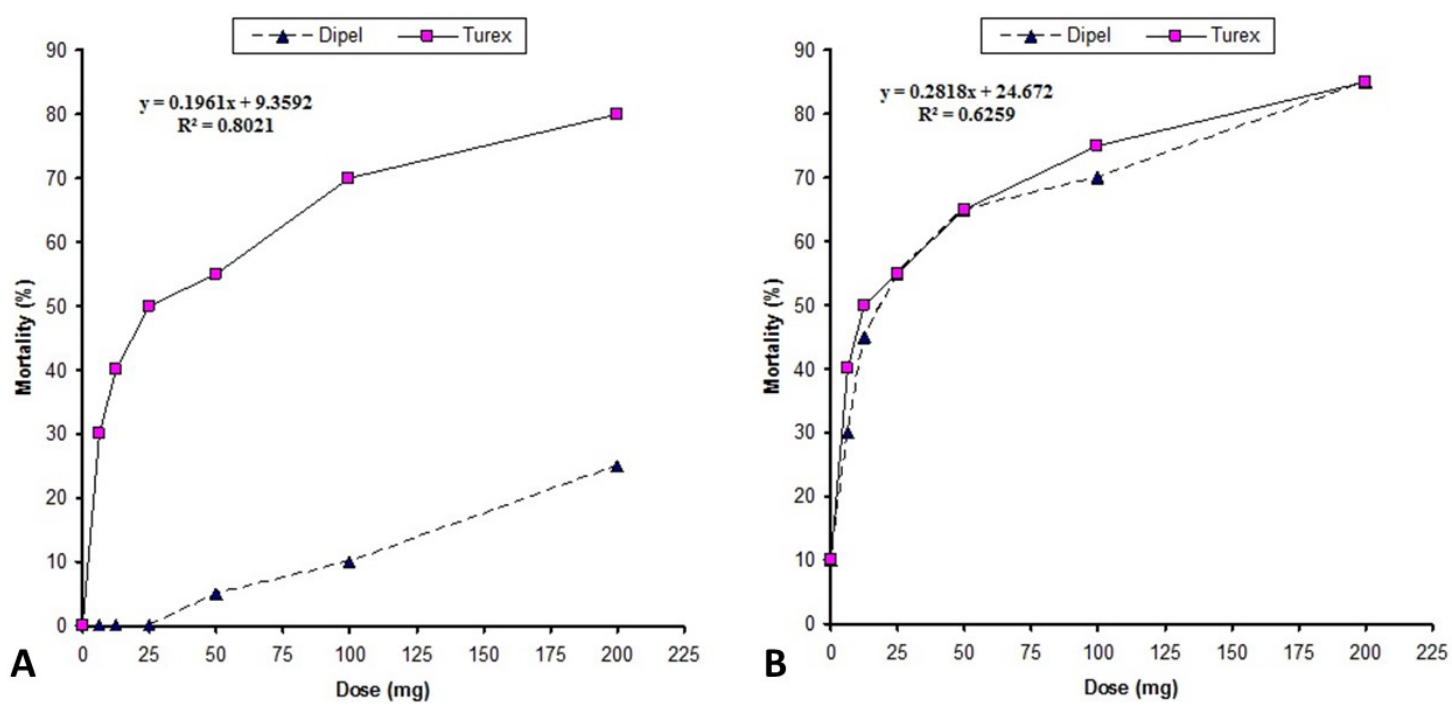

Fig. 3. Mortaity of $3^{\text {rd }}$ instar larvae Spodoptera litura against Dipel and Turex on $3^{\text {rd }}$ day (A) and on $7^{\text {th }}$ day (B) of application of insecticide.

These results are in agreement with those of other researchers; Dulmage and Cooperators (1981) revealed that $B$. thuringiensis strains that are active against the lepidopteron larvae differ greatly in their insecticidal spectra and potency. Murthy et al. (2014) found out that Bt results in higher larval mortality owing to improved solubility of crystal toxins in the alkaline midgut fluid due to their smaller size thus more toxin becomes available for binding with receptors on the surface of midgut epithelium resulting in rapid midgut paralysis. Pandey et al. (2009) reported that highest mortality $(73.3 \%)$ of third instar larvae of $S$. litura was caused at $10 \%$ concentration of commercial Btk formulation Biolep.
The highest mortality rates shown by Turex seems to be due to its high potency i.e., $32000 \mathrm{i} . \mathrm{u} / \mathrm{mg}$ which was greater as compared to the other formulation i.e. Dipel having the potency of $16,000 \mathrm{i} . \mathrm{u} / \mathrm{mg}$. The other reason for the highest performance of Turex may be its active ingredient i.e., the strain which is a mixture of subsp. Bt kurstaki and Bt aizawai. The active ingredient, in case of the other formulation Dipel is Bt kurstaki. The results not only concluded the efficacy of $B t$ as a good bio pesticide against Spodoptera litura (Fab.) but also revealed that $B t$ potency can be increased and it can be made more effective bio pesticide by using it in combination with other $B t$ strains or different insecticides (Saleem et al., 1995, 1996). Nathan 
et al. (2006) also found that bacterial toxins and botanical insecticides in combination were more effective against the rice leaf folder, Cnaphalocrocis medinalis even at low concentration as compared to their effect independently.
Sharma et al. (2001) performed leaf dip bioassay for a commercial formulation of $B t$ var. kurstaki and aizawai and evaluated that both the formulations caused 100 and 93.7 per cent mortality of $S$. litura larvae, respectively.

Table I. Mean mortalities of $1^{\text {st }}, 2^{\text {nd }}$ and $3^{\text {rd }}$ instar larvae of Spodoptera litura by Dipel and Turex after $3^{\text {rd }}$ and $7^{\text {th }}$ day of application $(n=4)$.

\begin{tabular}{|c|c|c|c|c|c|c|c|}
\hline \multirow{2}{*}{$\begin{array}{l}\text { Time } \\
\text { (Days) }\end{array}$} & \multirow{2}{*}{$\begin{array}{l}\text { Dose } \\
\text { (mg) }\end{array}$} & \multicolumn{3}{|c|}{ Dipel (Bt sub species kurstaki) } & \multicolumn{3}{|c|}{ Turex (Bt sub species kurstaki and aizawai) } \\
\hline & & $\begin{array}{l}1^{\text {st instar mortality }} \\
(\text { mean } \pm \text { SE })\end{array}$ & $\begin{array}{l}2^{\text {nd }} \text { instar mortality } \\
(\text { mean } \pm \text { SE) }\end{array}$ & $\begin{array}{l}3^{\text {rd }} \text { instar mortal- } \\
\text { ity }(\text { mean } \pm \text { SE) }\end{array}$ & $\begin{array}{l}1^{\text {st }} \text { instar mortali- } \\
\text { ty }(\text { mean } \pm \text { SE })\end{array}$ & $\begin{array}{l}2^{\text {nd }} \text { instar mortali- } \\
\text { ty }(\text { mean } \pm S E)\end{array}$ & $\begin{array}{l}3^{\text {rd }} \text { instar mortali- } \\
\text { ty }(\text { mean } \pm \text { SE })\end{array}$ \\
\hline \multirow[t]{8}{*}{3} & 0 & $0.00 \pm 0.00 \mathrm{~g}$ & $0.00 \pm 0.00 \mathrm{e}$ & $0.00 \pm 0.00 \mathrm{~h}$ & $0.00 \pm 0.00 \mathrm{~g}$ & $0.00 \pm 0.00 \mathrm{e}$ & $0.00 \pm 0.00 \mathrm{~h}$ \\
\hline & 200 & $45.83 \pm 4.17 \mathrm{bcd}$ & $29.17 \pm 4.1 \mathrm{~d}$ & $20.83 \pm 4.17 \mathrm{efg}$ & $75.00 \pm 4.81 \mathrm{a}$ & $70.83 \pm 4.17 \mathrm{a}$ & $66.67 \pm 6.80 \mathrm{a}$ \\
\hline & 100 & $37.50 \pm 7.98 \mathrm{cde}$ & $8.33 \pm 4.81 \mathrm{e}$ & $8.33 \pm 4.81 \mathrm{fgh}$ & $66.67 \pm 6.80 \mathrm{ab}$ & $62.50 \pm 4.17 \mathrm{ab}$ & $58.33 \pm 4.17 \mathrm{ab}$ \\
\hline & 50 & $25.00 \pm 10.7 \mathrm{~d}-\mathrm{g}$ & $4.17 \pm 4.17 \mathrm{e}$ & $4.17 \pm 4.17 \mathrm{gh}$ & $58.33 \pm 4.81 \mathrm{abc}$ & $54.17 \pm 4.17 \mathrm{abc}$ & $45.83 \pm 4.17 b c$ \\
\hline & 25 & $12.50 \pm 4.17 \mathrm{efg}$ & $4.17 \pm 4.17 \mathrm{e}$ & $0.00 \pm 0.00 \mathrm{~h}$ & $50.00 \pm 6.80 \mathrm{a}-\mathrm{d}$ & $45.83 \pm 4.17 \mathrm{bcd}$ & $41.67 \pm 4.81 \mathrm{bcd}$ \\
\hline & 12.5 & $8.33 \pm 4.81 \mathrm{fg}$ & $0.00 \pm 0.00 \mathrm{e}$ & $0.00 \pm 0.00 \mathrm{~h}$ & $41.67 \pm 4.81 \mathrm{bcd}$ & $41.67 \pm 4.81 \mathrm{~cd}$ & $33.33 \pm 6.80 \mathrm{cde}$ \\
\hline & 6.25 & $4.17 \pm 4.17 \mathrm{~g}$ & $0.00 \pm 0.00 \mathrm{e}$ & $0.00 \pm 0.00 \mathrm{~h}$ & $33.33 \pm 6.80 \mathrm{c}-\mathrm{f}$ & $29.17 \pm 4.17 \mathrm{~d}$ & $25.00 \pm 4.81 \mathrm{def}$ \\
\hline & Mean & $19.05 \pm 3.71 \mathrm{~B}$ & $6.55 \pm 2.16 \mathrm{~B}$ & $4.76 \pm 1.68 \mathrm{~B}$ & $46.43 \pm 4.80 \mathrm{~A}$ & $43.45 \pm 4.40 \mathrm{~A}$ & $38.69 \pm 4.29 \mathrm{~A}$ \\
\hline \multirow[t]{8}{*}{7} & 0 & $8.33 \pm 4.81$ & $8.33 \pm 4.81$ & $8.33 \pm 4.81$ & $8.33 \pm 4.81$ & $8.33 \pm 4.81$ & $8.33 \pm 4.81$ \\
\hline & 200 & $79.17 \pm 4.17$ & $79.17 \pm 4.17$ & $70.83 \pm 4.17$ & $83.33 \pm 0.00$ & $83.33 \pm 0.00$ & $70.83 \pm 7.98$ \\
\hline & 100 & $75.00 \pm 4.81$ & $75.00 \pm 4.81$ & $58.33 \pm 4.81$ & $83.33 \pm 0.00$ & $79.17 \pm 4.17$ & $62.50 \pm 4.17$ \\
\hline & 50 & $70.83 \pm 4.17$ & $70.83 \pm 4.17$ & $54.17 \pm 7.98$ & $79.17 \pm 4.17$ & $75.00 \pm 4.81$ & $54.17 \pm 7.98$ \\
\hline & 25 & $62.50 \pm 7.98$ & $62.50 \pm 7.98$ & $45.83 \pm 7.98$ & $75.00 \pm 4.81$ & $66.67 \pm 6.80$ & $45.83 \pm 4.17$ \\
\hline & 12.5 & $50.00 \pm 6.80$ & $58.33 \pm 4.81$ & $37.50 \pm 7.98$ & $62.50 \pm 4.17$ & $58.33 \pm 4.81$ & $41.67 \pm 10.76$ \\
\hline & 6.25 & $45.83 \pm 4.17$ & $50.00 \pm 6.80$ & $25.00 \pm 4.81$ & $58.33 \pm 4.81$ & $54.17 \pm 4.17$ & $33.33 \pm 6.80$ \\
\hline & Mean & $55.95 \pm 4.71 \mathrm{~B}$ & $57.74 \pm 4.65 \mathrm{~A}$ & $42.86 \pm 4.32 \mathrm{~A}$ & $64.29 \pm 4.90 \mathrm{~A}$ & $60.71 \pm 4.79 \mathrm{~A}$ & $45.24 \pm 4.36 \mathrm{~A}$ \\
\hline
\end{tabular}

In each row or column means with similar letter are statistically non-significant at $5 \%$ level according to Duncan Multiple range test. Small letters represent mean comparisons in each row and capital letters are used for mean comparisons between columns.

Table II. Toxicity of Dipel and Turex against $1^{\text {st }}, 2^{\text {nd }}$ and $3^{\text {rd }}$ instar larvae of Spodoptera litura after $3^{\text {rd }}$ and $7^{\text {th }}$ day of application $(\mathbf{n}=4)$.

\begin{tabular}{|c|c|c|c|c|c|c|c|c|}
\hline Insecticides & Time (Days) & Instar & $\mathrm{LC}_{50}($ mean $\pm \mathrm{SE})$ & FL at $95 \%$ & Chi-Square & DF & $\mathbf{n}$ & $\mathbf{p}$ \\
\hline \multirow{6}{*}{$\begin{array}{l}\text { Dipel (Bt sub spe- } \\
\text { cies kurstaki) }\end{array}$} & \multirow[t]{3}{*}{3} & $1^{\text {st }}$ & $144 \pm 49.70$ & $84.2-419.2$ & 0.204 & 4 & 140 & 0.995 \\
\hline & & $2^{\text {nd }}$ & $295 \pm 102.6$ & $185.3-1617.4$ & 0.504 & 4 & 140 & 0.973 \\
\hline & & $3^{\text {rd }}$ & $426 \pm 232.75$ & $218.5-16441.2$ & 0.393 & 4 & 140 & 0.983 \\
\hline & \multirow[t]{3}{*}{7} & $1^{\mathrm{st}}$ & $5.59 \pm 2.77$ & $0.8-11.3$ & 0.249 & 4 & 140 & 0.993 \\
\hline & & $2^{\text {nd }}$ & $3.45 \pm 2.47$ & $0.1-8.8$ & 0.133 & 4 & 140 & 0.998 \\
\hline & & $3^{\text {rd }}$ & $19.8 \pm 6.45$ & $7.9-35.4$ & 0.385 & 4 & 140 & 0.984 \\
\hline \multirow{6}{*}{$\begin{array}{l}\text { Turex (Bt sub } \\
\text { species kurstaki and } \\
\text { aizawai) }\end{array}$} & \multirow[t]{3}{*}{3} & $1^{\mathrm{st}}$ & $12.6 \pm 4.59$ & $3.9-22.6$ & 0.175 & 4 & 140 & 0.996 \\
\hline & & $2^{\text {nd }}$ & $15.9 \pm 5.84$ & $4.9-29.6$ & 0.228 & 4 & 140 & 0.994 \\
\hline & & $3^{\text {rd }}$ & $26.0 \pm 8.34$ & $11.1-49.7$ & 0.251 & 4 & 140 & 0.993 \\
\hline & \multirow[t]{3}{*}{7} & $1^{\mathrm{st}}$ & $3.50 \pm 1.74$ & $0.4-6.8$ & 0.962 & 4 & 140 & 0.915 \\
\hline & & $2^{\text {nd }}$ & $3.85 \pm 2.15$ & $0.4-8.1$ & 0.904 & 4 & 140 & 0.924 \\
\hline & & $3^{\text {rd }}$ & $14.1 \pm 5.84$ & $3.2-27.6$ & 0.245 & 4 & 140 & 0.993 \\
\hline
\end{tabular}

$\mathrm{LC}_{50}$ : lethal concentration at 50\% level; FL: fiducial limit at 95\% level; SE: significant error; $\mathrm{n}$ : Total no. of larvae/conc. level for all treatments + control. 
These results are supported by the findings of other workers who have determined the toxicity and specificity of pathogens against different insect groups (Jaquet et al., 1987; Dong et al., 2004). Jayanthi and Padmavathamma (2001) found that the microbial pesticides themselves and along with chemical insecticides revealed them best in controlling $S$. litura under glasshouse condition. $B$. thuringiensis $1 \times 10^{7}$ spores $/ \mathrm{ml}+$ fenvelerate 0.005 per cent was proved best in respect of highest larval population reduction $(89.90 \%)$ and lowest leaf damage $(20.15 \%)$. The highest pod yield (15.03 g/pant) was also recorded with the same treatment. Shahid et al. (2003) checked the efficacy of fungus (Metarhizium anisopliae) and bacterium (Bacillus thuringiensis) against rice stem borer and leaf folder and found a decrease in the population in both laboratory and field without any harmful effects on predators and thus proved the usefulness of bio-pesticides.

Discovery of the potent $B t$ strains in Diptera (Goldberg and Margalit, 1977) and Coleoptera (Krieg et al., 1983) also demonstrated that the spectrum of potential uses of $B t$ is wider than initially believed. Further investigations are required to determine the efficacy of different strains of $B t$ against other pests and also the effect of different combinations of $B t$.

\section{ACKNOWLEDGEMENT}

Author is heartily thankful to Dr. Munir Ahmad Associate Professor, Dr. Muhamad Asif Aziz Assistant Professor and Dr. Imran Bodlah Assistant Professor, Department of Entomology, Pir Mehr Ali Shah, Arid Agriculture University Rawalpindi for their cooperation and guidance in this research work.

\section{Statement of conflict of interest}

The Authors declares there is no conflict of interest.

\section{REFERENCES}

Abbot, S.W., 1925. A method of computing the effectiveness of an insecticide. J. econ. Ent., 18: 265-267. https://doi.org/10.1093/jee/18.2.265a

Ahmad, M., Arif, M.I. and Ahmad, M., 2007. Occurrence of insecticides resistance in field population of Spodoptera litura (Lepidoptera: Noctuidae) in Pakistan. Crop Protec., 26: 809-817. https://doi. org/10.1016/j.cropro.2006.07.006

Ahmad, M., Sayyed, A.H., Saleem, M.A. and Ahmad, M., 2008. Evidence for field evolved resistance to newer insecticides in Spodoptera litura
(Lepidoptera: Noctuidae) from Pakistan. Crop Protec., 27: 1367-1372. https://doi.org/10.1016/j. cropro.2008.05.003

Ahmad, M., 2008. Insecticide resistance, mechanisms, genetics and management of Spodoptera litura (Fab.) in the Punjab, Pakistan. Ph.D thesis, University College of Agriculture, Bahauddin Zakariya University, Multan Pakistan. pp. 120.

Anonymous, 1990. Bull. Eur. Pl. Prot. Org., 20: 399400. https://doi.org/10.1007/BF02970794

Anwar, T., Ahmad, I. and Tahir, S., 2014. Gas chromatographic analysis of pesticide residues in soil of Bahawalpur District, Punjab, Pakistan. Pakistan J. Zool., 46: 231-236.

Butter, N.S., Battu, G.S., Kular, J.S., Singh, T.H. and Brar, J.S., 1995. Integrated use of Bacillus thuringiensis Berliner with some insecticides for the management of bollworms in cotton. J. entomol. Res., 19: 255-263.

Dhir, B.C., Mohapatra, H.K. and Senapati, B., 1992. Assessment of crop loss in groundnut due to tobacco caterpillar, Spodoptera litura (F.). Indian J. Pl. Prot., 20: 215-217.

Ding, L.C., Hu, C.Y., Yeh, K.W. and Wang, P.J., 1998. Development of insect-resistant transgenic cauliflower plants expressing the trypsin inhibitor gene isolated from local sweet potato. $\mathrm{Pl}$. Cell Rep., 17: 854-860. https://doi.org/10.1007/ s002990050497

Dong, Y., Zhang, X.F., Xu, J.L. and Zhang, L.H., 2004. Insecticidal Bacillus thuringiensis Silences Erwinia carotovora virulence by a New Form of microbial antagonism, signal interference. Appl. environ. Microbiol., 70: 954-960. https://doi.org/10.1128/ AEM.70.2.954-960.2004

Dulmage, H.T, 1981. Insecticidal activity of isolates of Bacillus thuringiensis and their potential for pest control. In: Microbial control of pests and plant diseases (eds. H.D. Burges).Academic Press, London, pp. 193-222.

Falcon, L.A., 1971. Use of bacteria for microbial control of insects and mites (eds. Burges and Hussey). Academic Press, London, New York.

Finney, D.J. 1971. Probit analysis. $3^{\text {rd }}$ ed. Cambridge University Press London, UK. pp. 333.

Goldberg, L.J. and Margalit, J., 1977. A bacterial spore demonstrating rapid larvicidal activity against Anopheles sergentii, Uranotaenia unguiculata, Culex univittatus, Aedes aegypti and Culex pipiens. Mosquito News, 37: 355-358.

Islam, W., Ahmed, K.N. and Joarder, O.I., 1984. Timing and extent of damage caused by insect pests of 
green gram (Vigna radiate L.) in Bangladesh. Crop Protec., 3: 343-348. https://doi.org/10.1016/02612194(84)90040-1

Jaquet, F., Hutter, R. and Luthy, P., 1987. Specificity of Bacillus thuringiensis Delta-Endotoxin. Appl. environ. Microbiol., 53: 500-504.

Jayanthi, P.D.K. and Padmavathamma, K., 2001. Joint action of microbial and chemical insecticides on Spodoptera litura (Fab.) (Lepidoptera: Noctuidae). J. Trop. Agric., 39: 142-144.

Kranthi, K.R., Jadhav, D.R., Kranthi, S., Wanjaria, R.R., Ali, S.S. and Russell, D.A., 2002. Insecticide resistance in five major insect pests of cotton in India. Crop. Protec., 21: 449-460. https://doi. org/10.1016/S0261-2194(01)00131-4

Krieg, A., Huger, A.M., Langenbruch, G.A. and Schnetter, W., 1983. Bacillus thuringiensis var tenebrionis: ein neuer, gegenuber Larven von Coleopteren wirksamer Pathotyp. Z. angew. Ent., 96: 500-508. https://doi.org/10.1111/j.1439-0418.1983. tb03704.x

Loganathan, M., Babu, P.C.S., Balasubramanian, G. and Kailasam, C., 2002. Crop-pest damage model for groundnut infested with Spodoptera litura under field condition. Ind. J. Ent., 64: 484-492.

Murthy, S., Vineela, V. and Devi, P.S., 2014. Generation of nanoparticles from technical powder of the insecticidal bacterium Bacillus thuringiensis var. kurstaki for improving efficacy. Int. J. Biomed. Nanosci. Nanotechnol., 3: 236-250. https://doi.org/10.1504/IJBNN.2014.065470

Nathan, S.S., 2006. Effects of Melia azedarach on nutritional physiology and enzyme activities of the rice leaf folder, Cnaphalocrocis medinalis (Guenee) (Lepidoptera: Pyralidae). Pestic. Biochem. Physiol., 84: 98-108. https://doi. org/10.1016/j.pestbp.2005.05.006

Pandey, S., Joshi, B.D. and Tiwari, L.D., 2009. Relative efficacy of two subspecies of Bacillus thuringiensis, available as commercial preparations in market, on different stages of a lepidopteran pest, Spodoptera litura (Fabricius). Arch. Phytopathol. Pl. Protec., 42: 903-914. https://doi. org/10.1080/03235400701541255

Puntambekar, U.S., Mukhergiee, S.N. and Rangekar, R.K., 1997. Laboratory screening of different Bacillus thuringiensis strains against certain lepidopteran pests and subsequent field evaluation on the pod boring complex of Pigeon pea. Antonie Van Leewenhoeck. 71: 319-323. https://doi. org/10.1023/A:1000161206642

Parera, D.R., Armstrong, G. and Senanayake, N.,
2000. Effect of antifeedants on the diamondback moth (Plutella xylostella) and its parasitoid Cotesia plutellae. Pest Manage. Sci., 56: 486-490. https://doi.org/10.1002/(SICI)15264998(200005)56:5<486::AID-PS162>3.0.CO;2-O

Patil, R.S., Bhole, S.D. and Patil, S.P., 1991. Studies on biology and chemical control of Spodoptera litura. J. Maharashtra. Agric. Univ., 16: 66-68.

Puri, S.N., Murthy, K.S. and Sharma, O.P., 1998. Integrated management of cotton whitefly Bemisia tabaci Gennadius. In: Ecology and agricultural and sustainable development (eds. G.S. Dhaliwal, N.S. Randhawa, R. Arora and A.K. Dhwan), Indian Ecological Society, Punjab Agricultural University, Ludhiana and Center for Rural Research. pp. 250261.

Qin, H., Ye, Z., Huang, S., Ding, J. and Lou, R., 2004. The correlations of the different host plants with preference level, life duration and survival rate of Spodoptera litura Fabricius. Chin. J. Eco-Agric., 12: 40-42.

Russell, R.M., Robertson, J.L. and Savin, N.E., 1977. POLO: a new computer program for probit analysis. Bull. entomol. Soc. Am., 23: 209-213. https://doi. org/10.1093/besa/23.3.209

Saleem, M.A., Tufail, N. and Shakoori, A.R., 1995. Synergistic effect of synthetic pyrethroids on the toxicity of Bacillus thuringiensis as shown by the bio-chemical changes in the sixth instar larvae of Tribolium castaneum. Pakistan J. Zool., 27: 317323.

Saleem, M.A. and Shakoori, A.R., 1996. Synergistic effects of permethrin and cypermethrin on the toxicity of Bacillus thuringiensis in the adult beetles of Tribolium castaneum. Pakistan J. Zool., 28: 191-198.

Sondos, A., Mohamed, Badr, N.A. and FlHafezi, A.A., 2000. Efficacy of two formulations of entomopathogenic bacteria Bacillus thuringiensis against the first instar larvae of $S$. littoralis (Baisd). and Agrotis ipsilon (Hfn.) (Lepidoptera:Noctuidae). Egypt. J. agric. Res., 78: 1025-1040.

Sayyed, A.H., Ahmad, M. and Saleem, M.A., 2008. Cross-resistance and genetics of resistance to indoxacarb in Spodoptera litura (Lepidoptera: Noctuidae). J. econ. Ent., 101: 472-479. https://doi. org/10.1093/jee/101.2.472

Shahid, A.A., Nasir, I.A., Zafar, A.U., Sumrin, A., Chaudhry, B. and Riazuddin, S., 2003. The use of CAMB bio-pesticides to control pests of rice (Oryza sativa). Asian J. Pl. Sci., 2: 1079-1082. https://doi.org/10.3923/ajps.2003.1079.1082 
Sharma, S.S., Kaushik, H.D. and Kalra, V.K., 2001. Toxicity of Bacillus thuringiensis var. Kurstaki and aizawai against some lepidopterous pests. Annls. Biol., 17: 91-94.

Singh, K.N. and Sachan, G.C., 1992. Assessment of yield loss due to insect pests at different growth stages of groundnut in Pantnagar, Uttar Pradesh, India. Crop Protec., 11: 414-418. https://doi. org/10.1016/0261-2194(92)90023-X
Thanki, K.V., G.P. Patel and J.R. Patel. 2003. Population dynamics of Spodoptera litura on castor, Ricinus communis. Indian J. Ent., 65: 347-350.

Tinoco-Ojanguren, R. and Halperin, D.C., 1998. Poverty, production and health: inhibition of erythrocyte cholinesterase through occupational exposure to organophosphate insecticides in Chiapas, Mexico. Arch. environ. Hlth., 53: 29-35. https://doi.org/10.1080/00039899809605686 